\title{
CANOPY GAP DYNAMICS AND EFFECTS OF SELECTIVE LOGGING: A STUDY IN A PRIMARY HILL DIPTEROCARP FOREST IN MALAYSIA
}

\author{
Saiful $\mathbf{I}^{1} *$ \& Latiff A \\ ${ }^{1}$ Department of Botany, Faculty of Science and Technology, Universiti Kebangsaan Malaysia, 43600 Bangi, Selangor, \\ Darul Ehsan, Malaysia \\ *sislam47@hotmail.com
}

Submitted March 2018; accepted October 2018

\begin{abstract}
A systematic sampling was conducted in a primary hill dipterocarp forest of Peninsular Malaysia to evaluate the structure of the forest canopy before and after selective logging. The frequency distribution of gap area was strongly skewed. Before logging, the ridge had significantly higher gap area than hillside and ridgetop. However, after logging the canopy opening was much higher on the ridgetops due to high extraction of commercial trees. Unlike Brokaw's method of gap measurement, the photographic measurements of gap area showed reasonably stronger correlation. The results of selective logging showed reduction of overall canopy cover by an average of $21 \%$. Significant linear relationship was observed between loss of canopy trees and canopy opening. Due to variations in logging layout, the canopy openness varied significantly in the two study compartments. The opening of canopy was responsible for increased habitat heterogeneity followed by invasion of pioneer species. The effect of logging on percentage canopy loss was compared with a range of other studies. To maintain the canopy structure from destructive logging, this study strongly suggests site-specific cutting limit and adoption of appropriate harvesting plan, as well as skill development of forest workers and logging operators.
\end{abstract}

Keywords: Tree fall, gap measurement, gap size-distribution, fish eye photography, canopy openness, pioneers, harvesting plan

\section{INTRODUCTION}

Tropical forests are extremely dynamic, subject to a variety of disturbances, such as smallscale windstorms and tree falls or large-scale drought and climatic change (Huston 1994). The causes and nature of tree falls and their intensity leads to various sizes of canopy gaps, resulting in increased light to many smaller plants in the under storey (Green 1996, Brown 1996). Responses of various tree species to gap environments have been discussed (Denslow 1987). Spatial and temporal heterogeneity of tropical tree fall gaps play an important role in maintaining species composition and structure of the forest (Whitmore 1984, Saiful and Latiff 2017).

Microclimate conditions in small and large gaps have been discussed by Whitmore (1990). Spatial variations of microclimates under different sizes of canopy gaps and effects of selective logging have been reported (Saiful et al. 2010). Microclimate of small gaps and adjacent understorey is more or less similar, whereas in large gaps there is no difference of microclimate to that above the forest canopy (Whitmore 1990). This explains the differences in species composition for the two groups of tree species, climax and pioneers (Whitmore 1989).

The gap-size-frequency distribution can be a useful basis for comparing ecosystems (Denslow 1987). Green (1996) showed that $90 \%$ of canopy gaps were $120 \mathrm{~m}^{2}$ or smaller in area and the median gap area was $40-60 \mathrm{~m}^{2}$. The distribution of gap size was also strongly skewed. Few studies have examined the changes in canopy surface structure after logging (Uhl and Viera 1989, Crome et al. 1992). Harvested areas create a complex mosaic of undisturbed and disturbed forest comprising tree fall gaps, logging tracks and damaged canopy.

In planned logging, damage to forest canopy, trees and forest floor is insignificant (Johns et al. 1996, Pereira et al. 2002), but considerable 
damage was reported to forest canopy when the harvesting plan was imperfect (Saiful 2002). In several studies, gap size and canopy cover have been discussed as two recognised parameters in logging impact assessments (Crome et al. 1992, Cannon et al. 1994, Saiful 2002).

In tropical rainforest, tree species of $\geq 20 \mathrm{~cm}$ dbh generally determine the main canopy layer (Saiful \& Latiff 2017), and the dynamic features of the canopy after logging provide a good indicator for predicting the ecological soundness and sustainability of the operation (Clark et al. 1996). However, available studies show that there is lack of information on canopy gap dynamics of tropical hill dipterocarp rain forest before and after selective logging. The objectives of this study were to describe the structure and dynamics of rain forest canopy and examine the effects of selective logging in two adjacent compartments and discuss management implications.

\section{MATERIALS AND METHODS}

\section{Study site}

The study was carried out at Sungai Weng Catchment of Ulu Muda Forest Reserve, Kedah, Peninsular Malaysia ( $5^{\circ} 50^{\prime} \mathrm{N}, 100^{\circ} 55^{\prime} \mathrm{E}$ ). The study site is situated bordering Thailand at about
$40 \mathrm{~km}$ northeast of Baling, Kedah and composed of two adjacent compartments i.e. C28 and C29 (Figure 1 and 2). The topography is characterised by a hilly and undulating terrain with moderately steep to very steep slope, up to $45^{\circ}$. The elevation of the study area ranges from 340 to $600 \mathrm{~m}$ above sea level (Saiful 2002). The climate is uniformly hot, averaging about $25^{\circ} \mathrm{C}$ with mean annual precipitation averaging $2869 \mathrm{~mm}$. The parent material is primarily made up of quartzite and sandstone (RRIM 1988). The soil is red-yellow podzolic, well drained with $\mathrm{pH}$ ranging from 3.2-4.5 (Saiful 2002).

The vegetation is primarily hill dipterocarp forest and classified within the lowland evergreen rain forest formation (Whitmore 1984). It is a primary forest as indicated by bio-physical characteristics of the study area (Saiful 2002, Saiful et al. 2010). In general, the forest consists of three tree-canopy layers, i.e. the under storey layer, main canopy layer and scattered emergent layer (Saiful \& Latiff 2017).

\section{Sampling design}

A systematic sampling was adopted along the gradient directed transect in the 45 ha of study site for collection of data on canopy gap dynamics and other relevant information (Gillison and

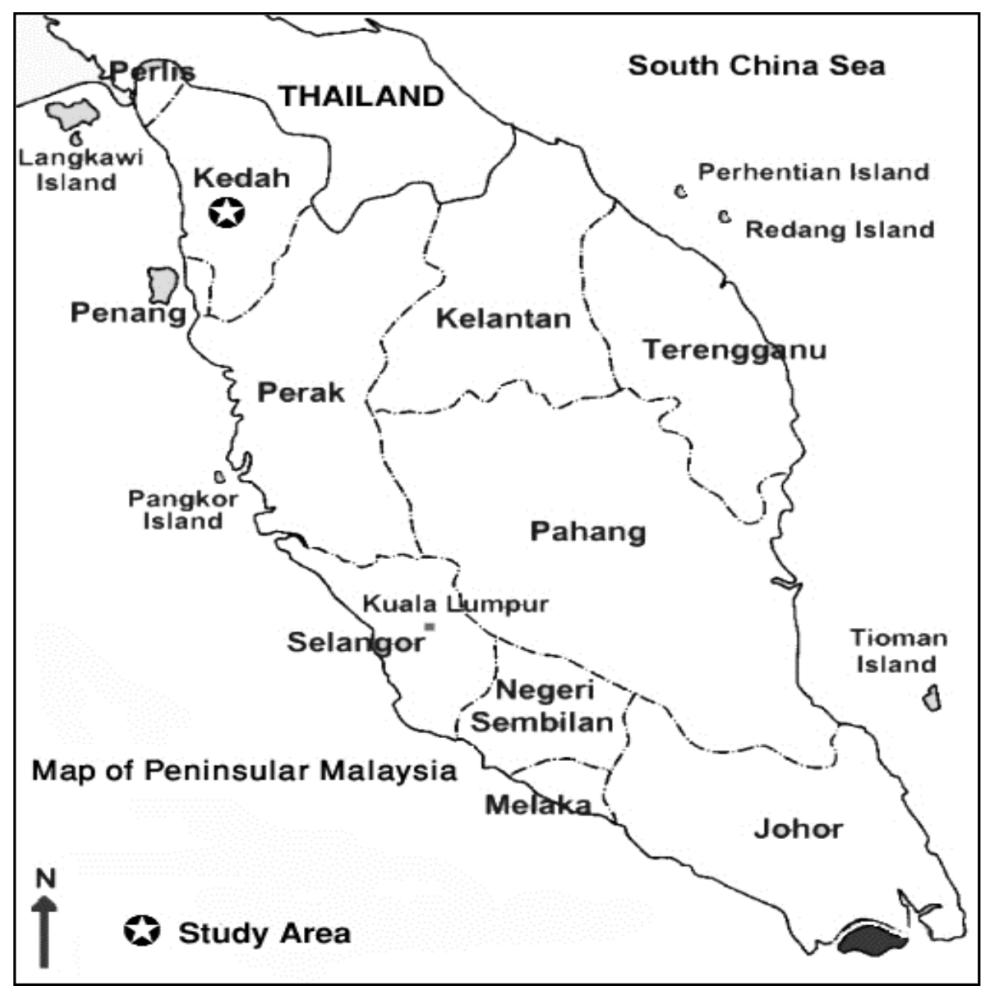

Figure 1 Map of Peninsular Malaysia showing the study location (Saiful \& Latiff 2014) 
Brewer 1985). The study site was stratified into ridge, ridgetop and hillside in order to capture the topographic variation of canopy structure. A line transect of about $500-550 \mathrm{~m}$ was laid out within each stand (i.e. hill) originating from stream bank, following the centre of the ridge and finally ended at the ridge crest (Figure 2). Lateral transects were established right angle to the main transect to sample hillsides, and spaced systematically at 40-m distance (Figure 3 ). Study plots of $30 \times 30 \mathrm{~m}$ or $20 \times 45 \mathrm{~m}$ were located at a 40-m distance on the transect line.

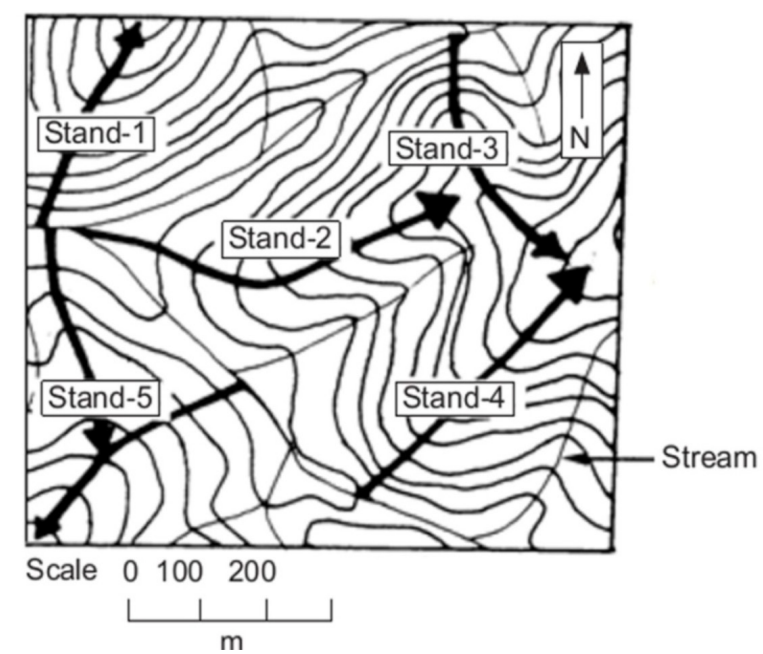

Figure 2 Topography of the study area showing direction of survey transects (indicated by arrow) along elevation gradient; lateral transects on hillsides are not shown; stands 1 (Compartment 29), 2 and 3 (Compartment 28) are selectively logged covering 45 ha (Saiful \& Latiff 2014)

\section{Data collection}

All canopy trees $\geq 20 \mathrm{~cm}$ dbh were measured with a diameter tape at $1.3 \mathrm{~m}$ above ground or just above the buttress. Tree position including trees marked for felling was mapped. After six months to one year of the completion of logging, resurveying of the same plots was done. The presence or absence of a tree was recorded including the soundness or injury. Basal area of trees $\geq 20 \mathrm{~cm}$ dbh was estimated using regression equation developed by Kato et al. (1978). Taxonomic identification of tree species is available elsewhere (Saiful 2002).

\section{Pre-logging gap measurements}

Various information such as number of gaps with respect to tree fall, gap size and canopy cover were recorded for every sample plot. Only trees of $\geq 20$-cm diameter were considered because these trees generally form the canopy layer. Tree fall gaps larger than $2 \mathrm{~m}^{2}$ were considered. The most frequently used vertical projection method of measuring canopy gap on the ground has not been appreciated because the actual gap influence area is beyond that of the vertically projected area (Brokaw 1982, Green 1996, Popma et al. 1988). On average, the size of the colonised area was 3.4 times larger than the size of the projected canopy opening (Popma et al.1988). Moreover, reliable ground measurements are much more difficult to obtain (Avery and Burkhart 1994, Saiful 2002). As such, canopy photographs using ground-level camera with 35-mm focal length lens at a distance of about

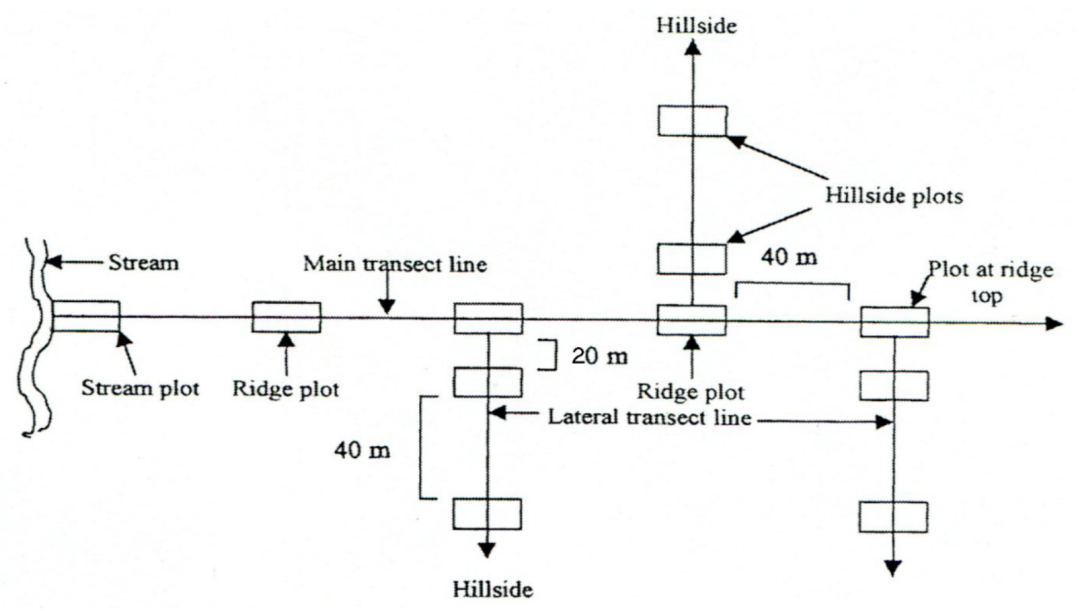

Figure 3 Diagram showing main and lateral transects and positioning of plots in a forest stand, lateral transects positioned alternately on either side of the main transect to sample hillside, study plots were regularly spaced on the transect line (Saiful \& Latiff 2014) 
$1.6 \mathrm{~m}$ from the ground were used to measure the individual gap size before logging, and using fish eye lens photographic estimates of post-logging canopy openness were determined (Evans and Coombe 1959, Whitmore et al. 1993). Before logging, fish eye photography could not capture the adjacent canopy gaps due to obstruction created by uneven-aged trees. In such case, fish eye photography may produce an overestimate of closure (Crome et al. 1992, Saiful 2002).

For estimation of pre-logging gap size, photographic scale was calculated following the procedure laid down for vertical aerial photograph (Slama 1980, Avery and Burkhart 1994). Accordingly, the scale ' $S$ ' of a gap photograph was determined by comparing the distance between two points $(\mathrm{a}, \mathrm{b})$ on the photograph with the corresponding ground distance $(\mathrm{AB})$. To adjust the difference in elevation between the points $\mathrm{A}$ and $\mathrm{B}$ on the ground, careful attention was paid for horizontal distance as near as possible. Similarly, tilting of camera from vertical position at the time of exposure was also avoided by holding camera as near vertical as possible. Without calculating the scale of every gap photograph, calculation of average photo scale of 25 randomly selected gaps covering all topographic locations was determined to increase the accuracy of subsequent photo measurements (Avery \& Burkhart 1994).

After determining the average photo scale (i.e. 1: 119.85), a transparent dot grid was positioned over gap photograph (Figure 4) and the area of each dot on the ground (i.e. $1 \mathrm{dot}=$ $0.144 \mathrm{~m}^{2}$ ) was then determined (see Appendix

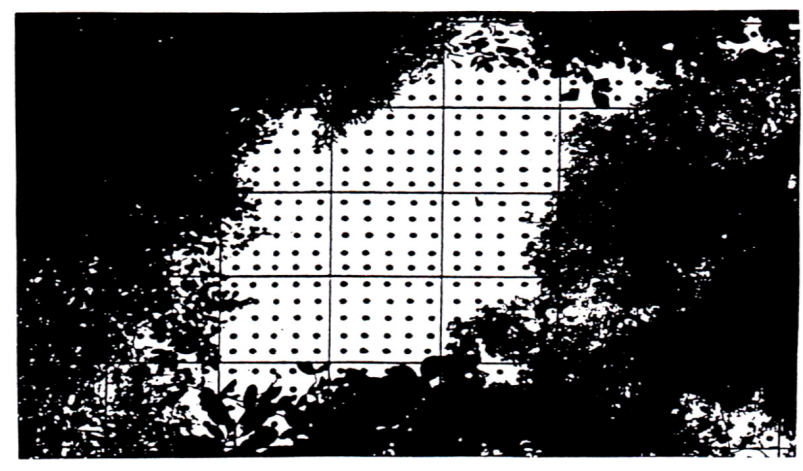

Figure 4 Transparent dot grid positioned over a canopy gap photograph for gap size determination; each dot represents a known area when used for a particular photographic scale
1). The total number of dots falling on the gap was counted (Figure 4). Multiplying the area of each dot with the total number of dots covered by each canopy gap determined the gap size.

\section{Post-logging gap estimation}

The percent canopy openness was calculated using fish eye photographs and measured as the ratio of canopy gaps and holes including any area of the open sky that is unobscured to the whole photograph area (Evans and Coombe 1959, Anderson 1964, Whitmore et al. 1993). By superimposing a dot grid to the fish eye photograph (Figure 5), the proportion of the total number of dots that falls on canopy gaps provided the estimates of canopy openness.

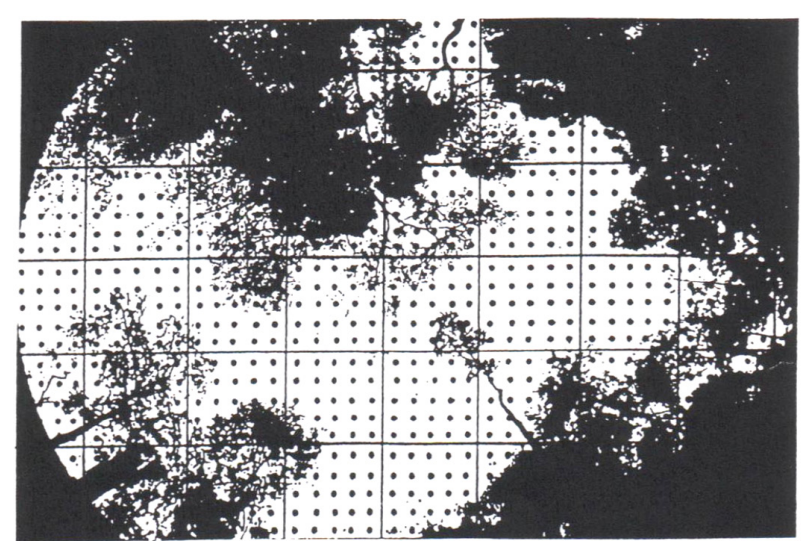

Figure 5 Transparent dot grid superimposed over a fish eye photograph to estimate per cent canopy openness; this photograph was taken from the centre of the study plot after six months of logging

Fish eye photographs were taken by fixing a fish eye lens onto a 35 -mm camera. The camera was pointed vertically upward into the canopy at about 1.6-m from the ground, and captured canopy openness from the centre of the study plots. Hemispherical or fish eye photography has become an important tool in ecological studies (Evans and Coombe 1959, Whitmore et al. 1993) and can be adapted to provide detailed information on the density and distribution of foliage of different habitat types (Magurran 1988).

\section{Methods of logging}

Harvestable trees ( $55 \mathrm{~cm}$ dbh for non-dipterocarp and $65 \mathrm{~cm}$ dbh for dipterocarp species) were 
marked using yellow plastic tags. Bulldozers were engaged for construction of logging tracks as well as to get timber out of the stump site. Felling was done by a power saw. The overall extraction level in 2.52 ha of sampled area was 27 trees ha-1 with basal area and volume removal of $19.39 \mathrm{~m}^{2}$ and $73.7 \mathrm{~m}^{3} \mathrm{ha}^{-1}$ respectively.

\section{Assessment of ground damage}

Damaged plot area by removal of top soil was positioned on a scaled graph sheet to assess the forest floor damage by logging tracks and log landing. Ground area disturbed by felling trees and skidding was also estimated. Transparent dot grid was used to determine the affected area.

\section{Data analysis}

One way Analysis of Variance (ANOVA) was applied to test for differences in mean values between different topographic positions. Where distributions were skewed, a non-parametric counterpart, Kruskal-Wallis test was performed. Mean comparison of the variables between two studied compartments were determined using one sample t-test. To determine the relationship between two sets of variables, a simple linear regression was also carried out. Statistical significance level was established at $\mathrm{p}<0.05$. Analysis was performed using the Minitab statistical package.

\section{RESULTS AND DISCUSSION}

\section{Tree fall and canopy gaps before logging}

Most of the canopy gaps were associated with single tree fall and most trees were found uprooted than snapping of the bole that conformed to Green (1996). The mean number of tree fall $(\geq 20-\mathrm{cm} \mathrm{dbh})$ and canopy gaps per plot were $3.87(\mathrm{SE}=0.33, \mathrm{n}=32)$ and 3.81 $(\mathrm{SE}=0.26, \mathrm{n}=32)$, respectively. Both tree fall and canopy gaps significantly varied by topographic locations, and ridgetop had lower number of tree fall (ANOVA, $\mathrm{F}=3.34, \mathrm{df}=2, \mathrm{p}<0.05$ ) and canopy gaps (ANOVA, $\mathrm{F}=3.82, \mathrm{df}=2, \mathrm{p}<0.05$ ) than the ridge, but did not differ significantly from hillside.

The number of tree fall was fairly correlated with the number of canopy gaps $\left(\mathrm{r}^{2}=50.5 \%\right.$, $\mathrm{p}<0.001, \mathrm{n}=32)$ as well as with the resulting gap size $\left(\mathrm{r}^{2}=57.7 \%, \mathrm{p}<0.001, \mathrm{n}=32\right)$. Similar observation on the increase of gap size with the number of tree fall has been shown (Van der Meer and Bongers 1996). Unlike Brokaw's (1982) vertical projection method of gap measurement, the photographic measurement of gap area showed reasonable and stronger correlation with the number of tree fall (Brokaw's method $\mathrm{p}<$ 0.05 vs. this method $\mathrm{p}<0.001)$. This could be due to the fact that photographic measurement takes full consideration of the actual gap perimeter (Figure 4).

\section{Gap size-frequency distribution}

Most gaps recorded were smaller in size in comparison with those reported elsewhere (Brokaw 1982, Green 1996), but similar to sizes reported by Thompson et al. (1992). The dissimilarity was perhaps due to the size range in those studies where gaps $<20 \mathrm{~m}^{2}$ were not included. Chapman and Chapman (1997) also reported $74 \%$ of the canopy gaps were $1 \mathrm{~m}$ wide or less. The frequency distribution of the gap area of the study plots was strongly skewed and median gap area was $50.40 \mathrm{~m}^{2}$. That is $5.6 \%$ of the plot area was covered by canopy gaps. However, out of 32 plots, twelve plots $(37.5 \%)$ were $<30 \mathrm{~m}^{2}$ gap area, ten $(31.2 \%)$ were $>30-70 \mathrm{~m}^{2}$, eight $(25 \%)$ were $>70-130 \mathrm{~m}^{2}$ and two plots $(6.2 \%)$ were $>130 \mathrm{~m}^{2}$ gap area. Like gap area estimates, the distribution of canopy cover of the study plots was also strongly skewed and median canopy cover was $94.4 \%(\mathrm{n}=32)$.

\section{Gap size and species distribution}

The variation of species composition and richness in the study site may partly be associated with the size of the canopy gaps and gap environment (Saiful 2002). Among the topographic locations, ridge and hillsides had significantly higher median plot area occupied by canopy gaps than ridgetops (Table 1, Figure 6). Stand profiles of the study site also showed that ridges and hillsides were mostly interrupted by tree fall gaps (Saiful \& Latiff 2017). However, remarkable representation of pioneer species (e.g. Macaranga and Mallotus) was observed on the ridges and hillsides before logging (Saiful 2002), which was probably because of wider plot area occupied by 
Table 1 Kruskal-Wallis tests on comparison of median values on gap area estimates within the study plots, Ulu Muda Forest Reserve, Kedah in different topographic locations before logging

\begin{tabular}{llccc}
\hline Variable & Habitat & Sample size $(\mathrm{n})$ & Median value & P-Value \\
\hline Plot area $\left(\mathrm{m}^{2}\right)$ covered & Hillside & 11 & 38.70 & \\
by canopy gaps & Ridge & 11 & 82.50 & $0.013^{*}$ \\
& Ridgetop & 10 & 19.30 & \\
\hline
\end{tabular}

$*$ significance level at $\mathrm{p}<0.05$
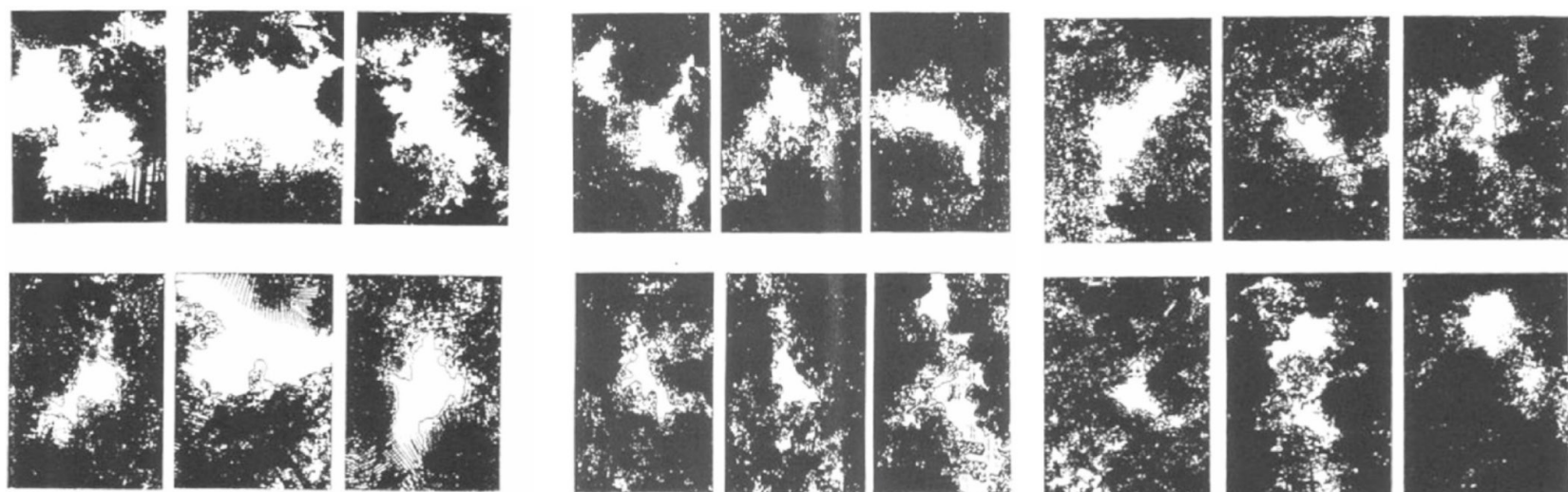

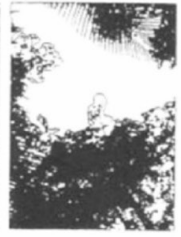

(a)

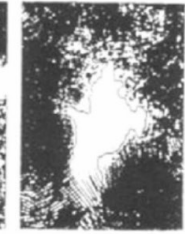

i.
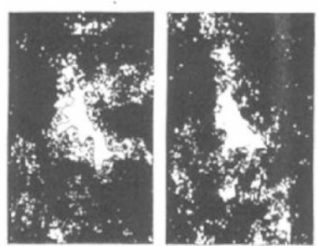

(b)
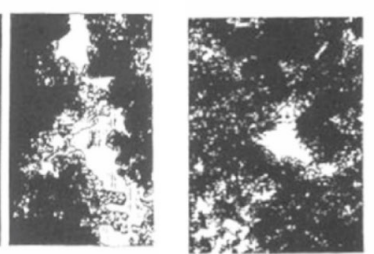

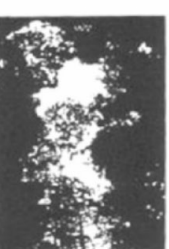

(c)

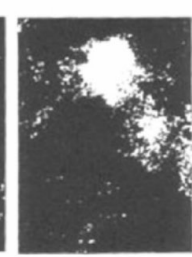

Figure 6 Vertical canopy photographs using 35-mm focal length lens showing size and shape of the canopy gaps in the study site before logging; gaps on the ridges (a) are bigger in size followed by hillside (b) and ridgetop (c)

the canopy gaps. Similarly, the overall dominant representation of climax (non-pioneer) species was also attributed to small sized gaps (Saiful 2002) and this finding was consistent with the study of Whitmore (1989). The presence of more shade-tolerant climax species of the study site is comparable with the forests of Barro Colorado Island (Brokaw and Scheiner 1989).

\section{Canopy opening after logging}

Based on the fish-eye photography, the distribution of plot data on percentage canopy openness was strongly skewed. Out of 28 study plots, twelve plots $(43 \%)$ had $<25 \%$ canopy openness, ten plots $(36 \%)$ had $25-50 \%$ and six plots $(2 \%)$ were with $>50 \%$ canopy opening. The mean canopy openness (log transformed) was $29.2 \%(\mathrm{SE}=1.11, \mathrm{n}=28$, range $12-80.6 \%)$ and corresponding median canopy cover was $73 \%(\mathrm{n}=28)$.

\section{Harvesting damage and canopy openness}

The occurrence of various types of harvesting damage (smashed, snapped bole, crown injury) to canopy trees was significantly higher on the ridgetops than hillsides and ridges (ANOVA, $\mathrm{F}=4.68, \mathrm{df}=2, \mathrm{p}<0.05)$ which may have played higher canopy opening on ridge crest $(41.50 \%)$. In fact, ridgetop was heavily harvested $(41 \%$ of total extracted trees) followed by $33.8 \%$ and $25 \%$ for ridge and hillside, respectively. However, across all habitat types, significant linear relationship was observed between the loss of overstorey canopy trees and increase in canopy openness $\left(\mathrm{r}^{2}=76 \%, \mathrm{p}<0.001\right.$, $\mathrm{n}=28$ ) (Figure 7). Similar logical relationship was also exist between canopy openness with the amount of basal area decline for trees $\geq 20 \mathrm{~cm}$ dbh $\left(r^{2}=46 \%, p<0.000, n=28\right)$. From West Kalimantan, Indonesia, Cannon et al. (1994) reported linear relationship between basal area 


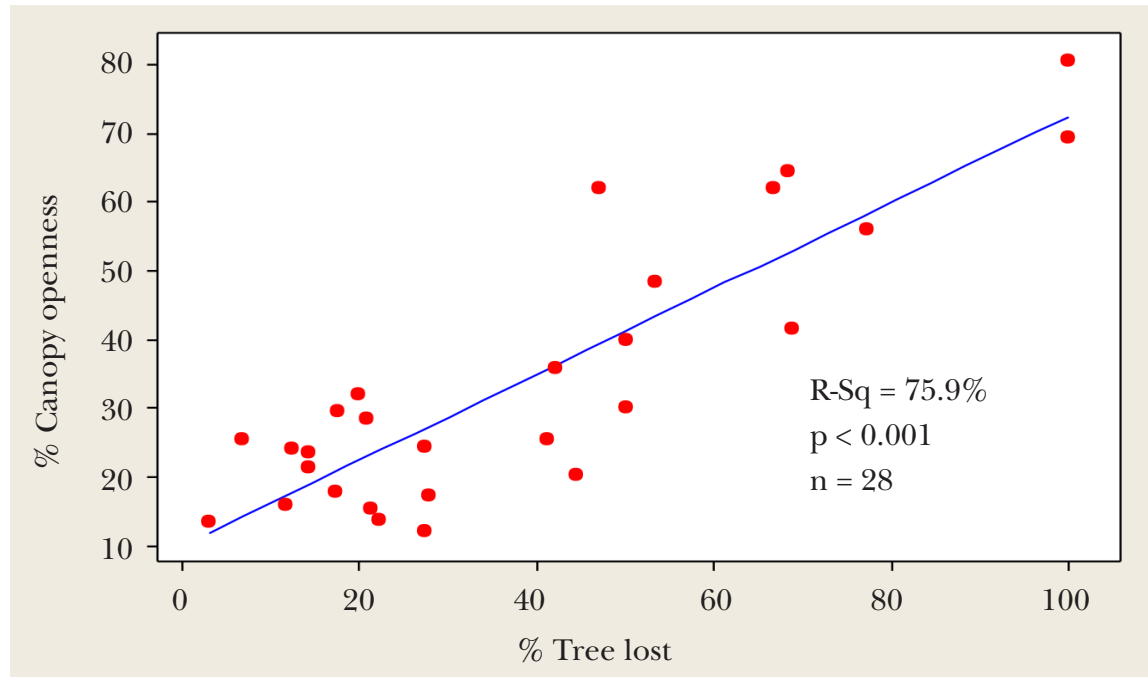

Figure 7 Relationship between loss of overstorey canopy trees ( $\geq 20$-cm diameter) and percent canopy openness in the study site; $\mathrm{n}=$ number of plot sampled

harvest $\left(\mathrm{m}^{2}\right.$ ha- 1$)$ and canopy disturbance $\left(\mathrm{r}^{2}=\right.$ $0.51)$. In the Amazon, increased tree fall rates in logged forest were related to increased canopy opening (Schulze \& Zweede 2006).

\section{Effects of harvesting plans and canopy opening}

The intensity of ground damage by logging tracks and skidding was primarily responsible for incidental damage to trees which ultimately had affected canopy structure. As such, significant linear relationship between intensity of ground damage and canopy openness $\left(\mathrm{r}^{2}=63 \%, \mathrm{p}<0.001\right)$ was obtained (Figure 8). The effects of harvesting layout of the two study compartments were studied (Figure 9 and 10). Though basal area and volume removal of both compartments were not statistically significant $(\mathrm{t}$ $=0.15, \mathrm{p}=0.88, \mathrm{df}=25$ ) (Saiful 2002), however, mean ground damaged area for all kinds of logging tracks and log decks combined was significantly higher in C29 than C28 $(\mathrm{t}=3.41, \mathrm{df}=$ $17, \mathrm{p}<0.01)$, and $56.6 \%$ of the total area affected was contributed by skid tracks alone followed by log landing $(27.2 \%)$ and roads $(16.3 \%)$.

The high percentage of ground damage in C29 could be mainly due to positioning of logging tracks along the centre of the ridge and ridge tops, where most merchantable trees were dominated. In contrast, the positioning of logging tracks away from the centre of the ridge as well as their low frequency was perhaps the key factor in reducing damage in C28. As a result, extensive ground damage inside the study plots of C29 was significantly related with canopy opening $\left(\mathrm{r}^{2}=73 \%, \mathrm{p}=0.000\right)$, and the low frequency of logging tracks and corresponding undisturbed area in C28 showed poor linear relationship $\left(r^{2}=26 \%, p=0.052\right)$. However, due to variation in canopy openness $(\mathrm{t}=4.41, \mathrm{df}=15, \mathrm{p}<0.001)$, the overall density and distribution of foliage in C28 was much higher than the C29 (Figure 11 and Figure 12).

Study of Pinage et al. (2016) showed that contribution of log decks and primary roads in the decrease of canopy cover were significant at a $95 \%$ confidence level, while the effect of secondary roads, tree fall gaps and skid trails were not. A gradient of increasing gap fraction that ranged from primary forests to log decks was also observed in selectively logged forests in Western Amazon (Pinagé et al. 2014). Log decks had the largest forest gap fractions at $0.5 \mathrm{yr}$ post-harvest than roads and skid tracks. Selective logging in Myanmar reported highest canopy openness in log landing and showed favorable growth of teak seedlings due to increased light intensity (Ne Win et al. 2012).

\section{Invasion of pioneer species}

The variation of forest microclimates following logging has been elaborately discussed by Saiful et al. (2010). As such, the increase in air temperature had decreased the percentage 


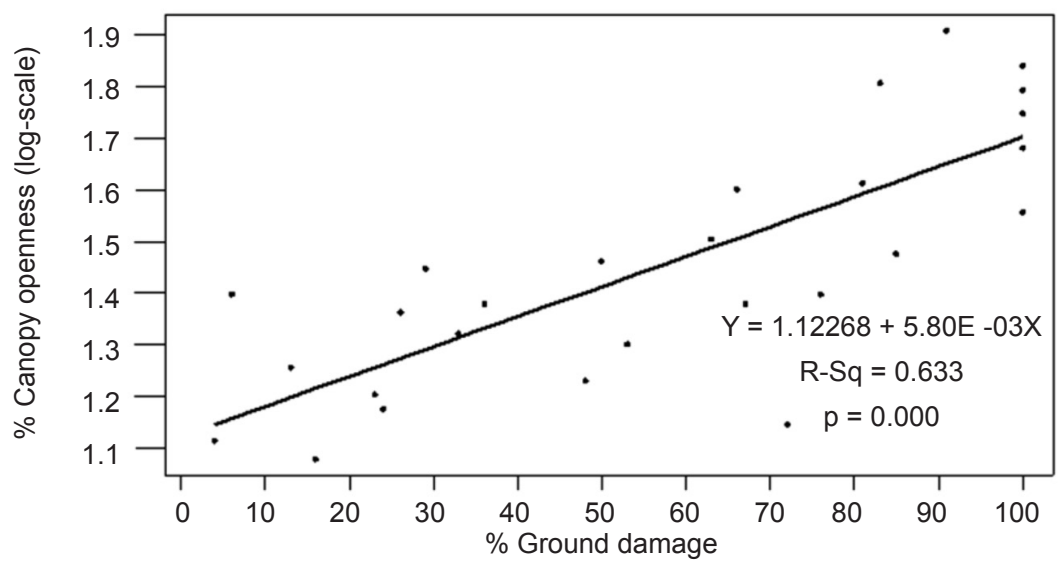

Figure 8 Relationship between intensity of ground damage and canopy openness in the study area, Ulu Muda Forest Reserve, Kedah

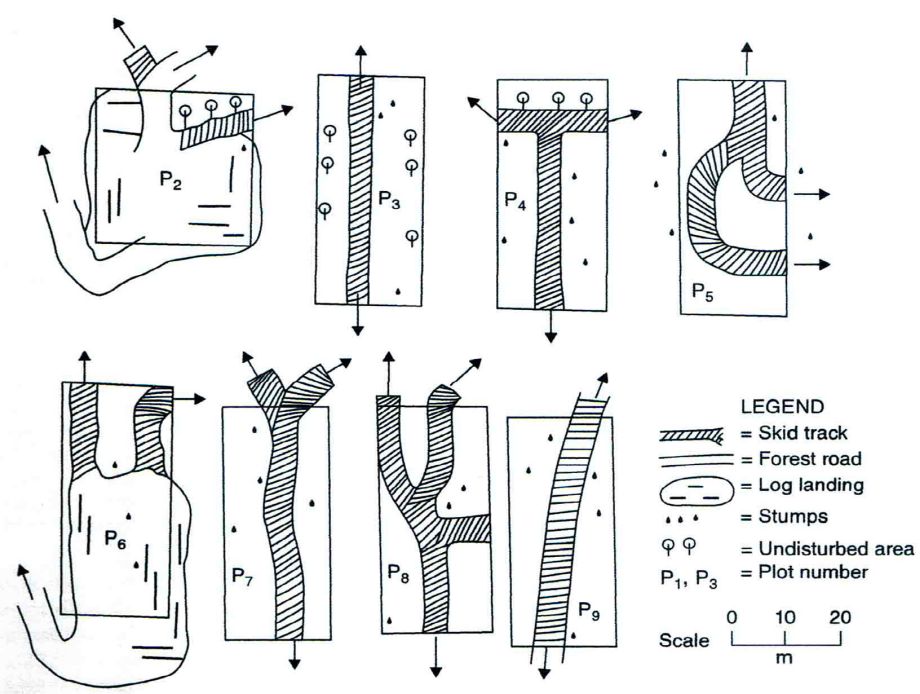

Figure 9 Harvesting layouts inside the study plots of compartment 29 showing positioning of logging tracks and their pattern, harvested tree stumps and undisturbed plot (Saiful 2002)

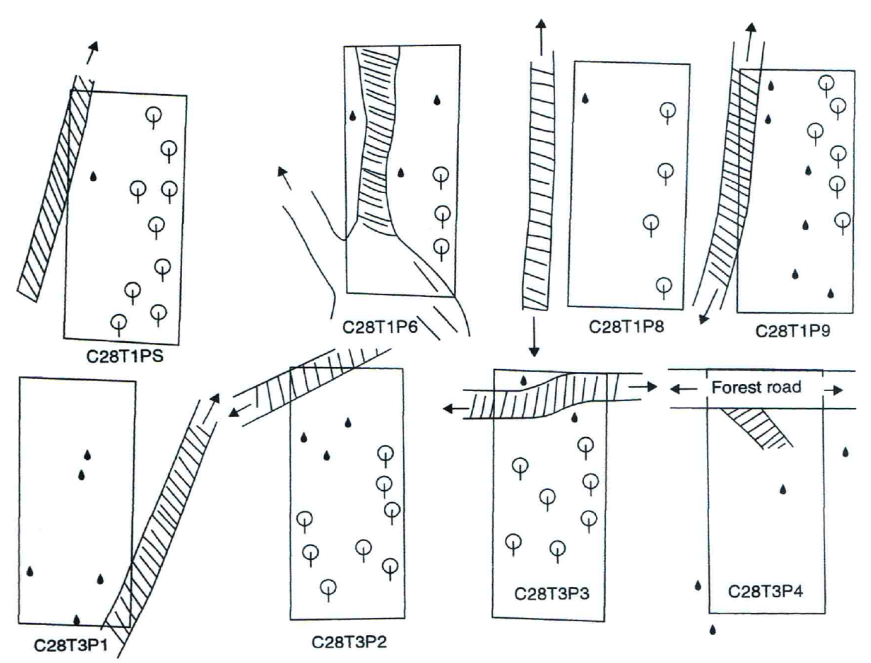

Figure 10 Harvesting layouts in compartment 28 showing position of logging tracks passing at a distance from the study plots, causing minimum damage to trees; see Figure 9 for legend (Saiful 2002) 


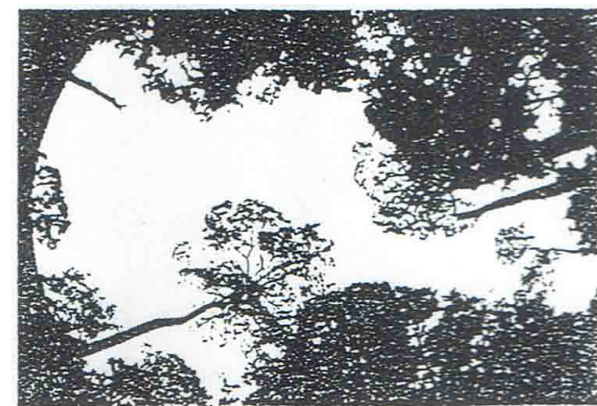

C29T1P8, ridge top

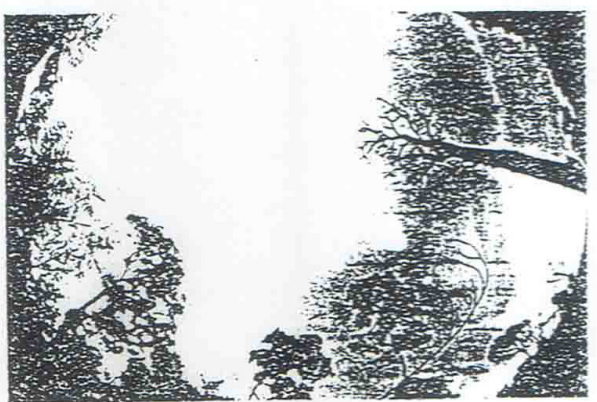

C29T1P9, ridge top

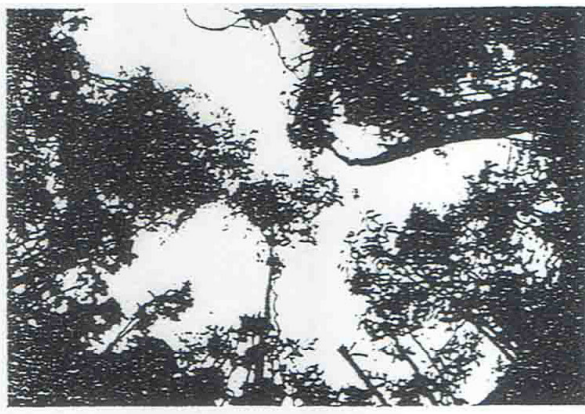

C29T2P2, hillside

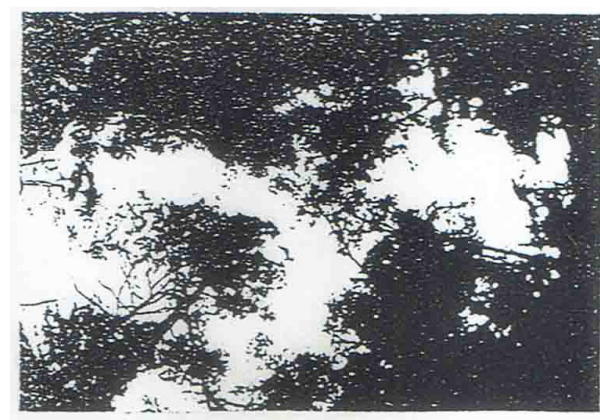

C29T1P3, ridge

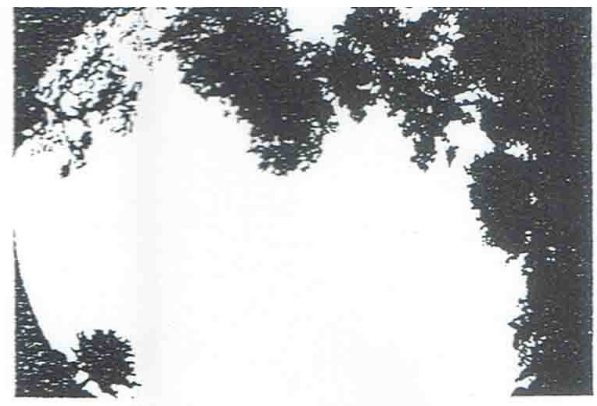

C29T2P3, hillside

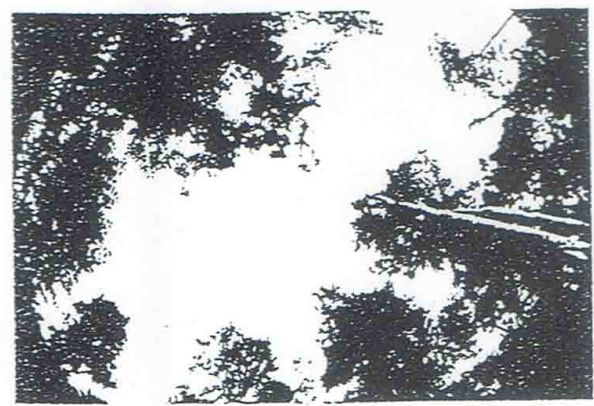

C29T2P4, hillside

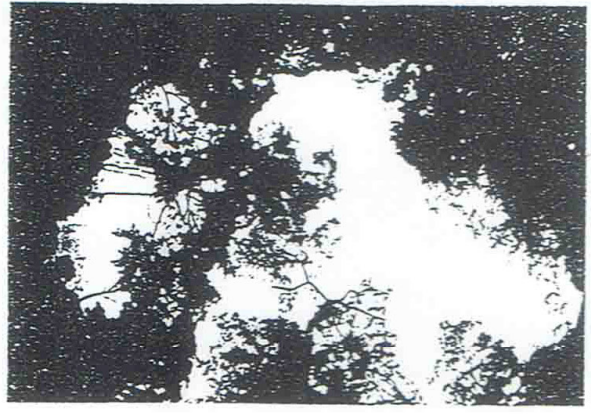

C29T2P1, hillside

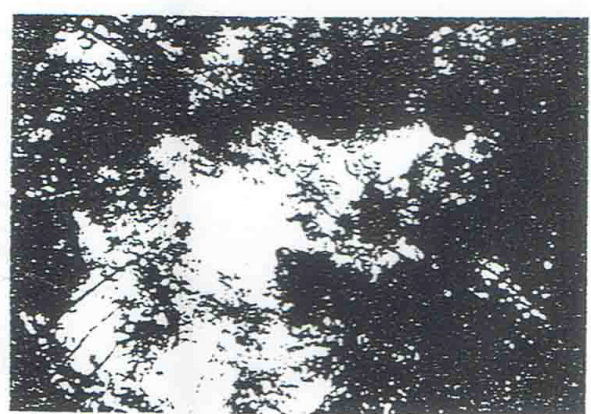

C29T2P6, hillside

Figure 11 Fish eye photographs of study plots showing much lower density and distribution of foliage in compartment 29 due to high percentage of ground damage and loss of canopy trees

of relative humidity $\left(\mathrm{r}^{2}=0.472, \mathrm{p}<0.001\right)$ and increased soil temperature $\left(r^{2}=0.450\right.$, $\mathrm{p}<0.001)$. Fish eye photography of the loggedover forest depicted increased light intensity on the forest floor because of lesser stratification of canopy layers. Light availability to the forest understorey was significantly higher in the regenerating forest of Pasoh Forest Reserve (Numata et al. 2006).

The overall changes in similarity of species composition by logging might be coupled with additional changes by invasion of pioneer species due to canopy opening (Saiful et al. 2010, Saiful and Latiff 2014). Interestingly, one particular 


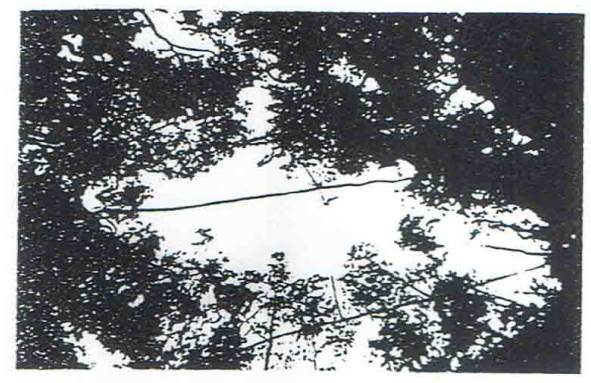

C28T3P1, ridge top

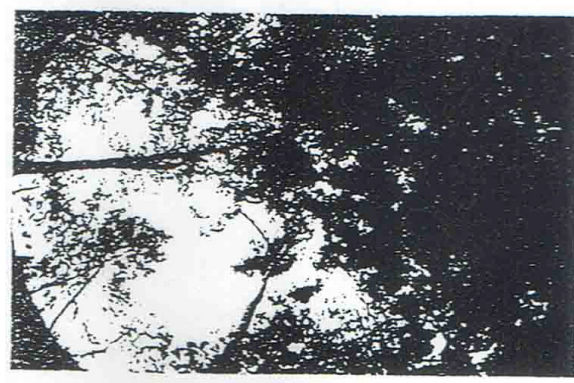

C28T1P9, ridge top

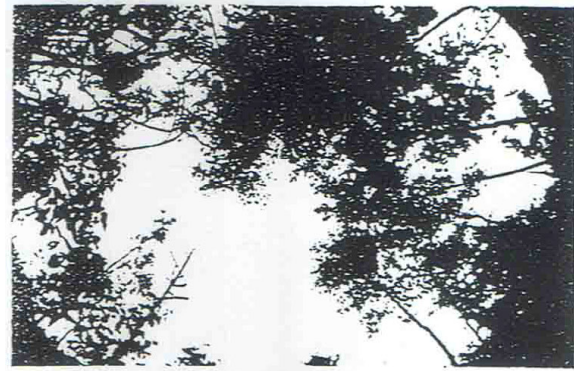

C28T2P4, hillside

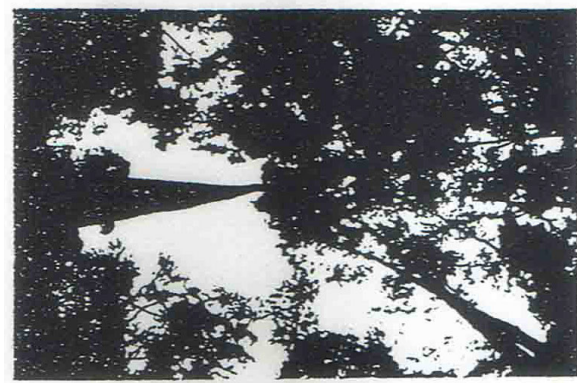

C28T4P1, hillside

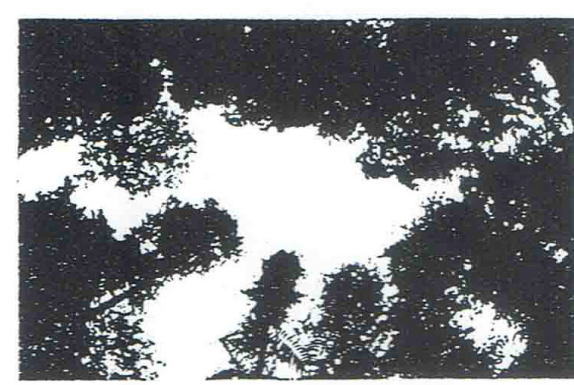

C28T1P2, ridge

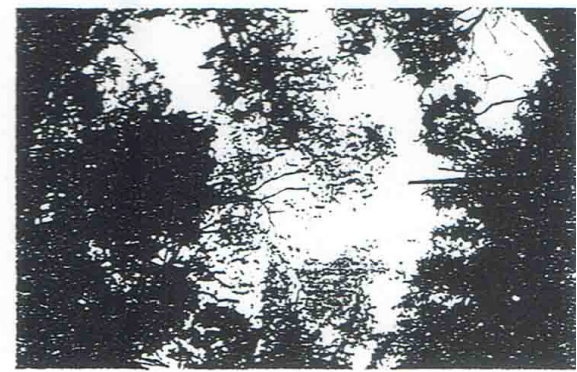

C28T1P3, ridge

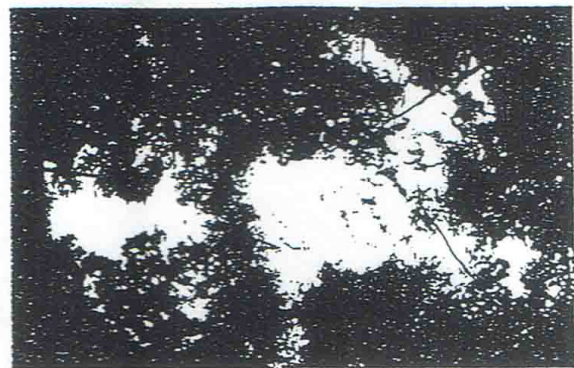

C28T3P3, ridge

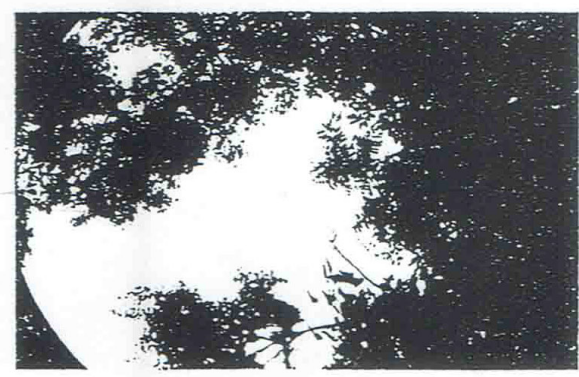

C28T3P4, ridge

Figure 12 Fish eye photographs of study plots of compartment 28 showing much higher density and distribution of foliage due to low percentage of ground damage and higher retention of canopy trees

pioneer species (Trema angustifolia, Ulmaceae) was predominant in the heavily-damaged logged area (i.e. C29), which was not observed before logging, whereas in the lightly-damaged compartment (C28), members of the genus Macaranga were quite frequent. Seino et al. (2005) also observed a similar trend of species dominance of Macaranga in Tangkulap Forest Reserve in Sabah, Malaysia. In Southeast Asia, the invasion of members of the family Euphorbiaceae (e.g. Macaranga, Mallotus spp.) in logged-over forest is well recognised (Johns 1988, Cannon et al. 1998).

\section{Comparisons with other studies}

Most of the study plots had 90-98\% canopy cover before logging. The median canopy cover 
Table 2 Comparison of canopy loss between different studies under conventional logging

\begin{tabular}{|c|c|c|c|c|c|}
\hline \multirow[t]{2}{*}{ Studies } & \multicolumn{2}{|c|}{ \% Canopy opening } & \multicolumn{2}{|c|}{$\%$ Canopy cover } & \multirow[t]{2}{*}{$\%$ Canopy loss } \\
\hline & $\begin{array}{l}\text { Before logging/ } \\
\text { unlogged forest }\end{array}$ & $\begin{array}{l}\text { After logging/ } \\
\text { logged forest }\end{array}$ & $\begin{array}{l}\text { Before logging/ } \\
\text { unlogged forest }\end{array}$ & $\begin{array}{l}\text { After logging/ } \\
\text { logged forest }\end{array}$ & \\
\hline Webb 1997 & - & - & 91.4 & 73.4 & $18^{\wedge}$ \\
\hline Uhl and Viera 1989 & & & 80.0 & 42.5 & 37.5 \\
\hline This study 2002 & 5.6 & 29.2 & 94.4 & 73.0 & 21.4@ \\
\hline Verissimo et al. 1992 & - & - & 82 & 45 & 37 \\
\hline Crome et al. 1992 & - & - & - & - & $22.3^{\wedge \wedge}$ \\
\hline Johns et al. 1996 & - & - & - & - & $19 \#$ \\
\hline Cannon et al. 1994 & - & 45 & 76 & - & - \\
\hline Periera et al. 2002 & 3.1 & 21.6 & 97 & 75.4 & 21.6 \\
\hline
\end{tabular}

$\wedge$ = controlled selective logging, $\wedge^{\wedge}=$ measured by aerial photograph and ground survey, $\#=$ measured by holding viewfinder along transects, @ = measured by ground-based vertical canopy photography using 35-mm focal length lens

for the study area (45 ha) was $94.4 \%(\mathrm{n}=32)$. Conventional logging published in different studies (Table 2) shows percentage removal of the original canopy cover. In the present study, logging decreased canopy cover by an average of $21 \%$ overall which is comparable to other studies except Uhl and Viera (1989) and Verissimo et al. (1992). Different studies adopted different methodologies for estimation of canopy loss but information for comparison was largely lacking. Webb's (1997) study on controlled selective logging showed lowest canopy loss (Table 2). Queensland study (Crome et al. 1992) showed less incidental damage to trees that resulted in $22.3 \%$ canopy loss. However, the lower value for the study site was mainly due to the contribution from C28 that was lightly logged in terms of frequency of logging tracks and damage to trees. With an exception of this study, other research compared unlogged forest with sites logged at different years prior to sampling (Table 2).

\section{Implications for management}

The residual stocking standards for the next cut in Malaysian Selective Management System (SMS) should have at least 32 sound commercial tree species per ha in the diameter class of 30-45 cm (Yuan et al. 1996). The SMS could not qualify this standard in the residual stock (Saiful 2002), and this resulted in even-aged appearance of the forest with significant canopy opening. Due to before-and-after logging study, the effects of logging on availability of required number of economically important trees for the next cut had been precisely quantified (Saiful 2002). That is, the next felling operations would have different species list of rather poor commercial importance.

Moreover, the condition of residual stocking agrees that it would need more than one rotation to recover stand structure and canopy development. However, the recovery is largely dependent on the resilience of the residual species and their competition with pioneers. Post-logging growth of commercial tree species in the forest of Vietnam revealed that a duration of 30 years was insufficient to recover the status similar to unlogged forest (Do et al. 2016). There was limited evidence of canopy development after 8 years of selectively logged lowland rainforest (Cannon et al. 1994). It was also estimated that the gap pattern would be restored to a condition similar to undisturbed forest in about 53 years after logging (Priatna et al. 2004). Similar slower canopy recovery was reported on logging roads than on skid trails (Soemarno 2001).

This study proposes some improvements in harvesting operation. Harvesting plan should be drawn up in advance considering both exploitable trees and trees for retention. Trees for next cut (near to the exploitable trees) should be marked separately so that logging operators can avoid damages to these trees. A site-specific cutting rule would reduce the canopy opening and damage in areas dominated by commercial trees. Besides, enhancing the skills of forest workers and logging operators are important contributing factors in reducing damage to the residual trees and the forest canopy. 


\section{CONCLUSIONS}

Gap dynamics is a biophysical variable related to micro-climate and regeneration, and is an important indicator of forest management quality. In this study, although there was no significant difference in harvesting intensities (basal area or volume felled) in the two studied compartments, imperfect logging layout showed significant logging damage to compartment 29, which was a significant research issue. In fact, it was assumed that both compartments could have been affected similarly due to similar extraction level. However, logging method was responsible for canopy disturbance, not harvesting intensity. The approach proposed in this study findings is useful for ensuring success of forest conservation and sustainable forest management. Trial and evaluation for low impact logging of highly rich Shorea curtisii stand along the ridgetops needs research support. Monitoring studies at different ages of logging on the changes of recovery of the canopy structure would facilitate the management to prepare an improved management plan.

\section{ACKNOWLEDGEMENTS}

The authors are indebted to IRPA Project Grant No. 08-02-02-0009 for financial assistance. Cooperation from the State Forestry department, Kedah, Malaysia is also greatly acknowledged. The authors would also like to thank the director and curator of FRIM Herbarium for permission to examine tree specimens.

\section{REFERENCES}

ANDERson MC. 1964. Studies in woodland light climate. I. The photographic computation of light conditions. Journal of Ecology 542: 27-41.

Avery TE \& Burkhart HE. 1994. Forest Measurements. $4^{\text {th }}$ edition. McGraw-Hill Book Company, New York.

BRokaw NVL. 1982. The definition of treefall gap and its effect on measures of forest dynamics. Biotropica 14: 158-160.

Brokaw NVL \& SCheiner SM. 1989. Species composition in gaps and structure of a tropical forest. Ecology 70 : 538-541.

Brown N. 1996. A gradient of seedling's growth from the centre of a tropical rain forest canopy gap. Forest Ecology and Management 82: 239-244.

Cannon CH, Peart DR, Leighton M \& Kartawinata K. 1994. The structure of lowland rainforest after selective logging in West Kalimantan, Indonesia. Forest Ecology and Management 67: 49-68.
Cannon CH, Peart DR \& Leighton M. 1998. Tree species diversity in commercially logged Bornean rainforest. Science 281: 1366-1368.

Chapman CA \& Chapman LJ. 1997. Forest regeneration in logged and unlogged forests of Kibale National Park, Uganda. Biotropica 29: 396-412.

Clark DB, Clark DA, Rich PM, Weiss S \& Oberbauer SE. 1996. Landscape scale evaluation of understory light and canopy structure: methods and application in a neotropical lowland rain forest. Canadian Journal of Forestry Research 26: 747-757.

Crome FHJ, Moore LA \& Richards GC. 1992. A study of logging damage in upland rainforest in North Queensland. Forrest Ecology and Management 49: 1-29.

Denslow JS. 1987. Tropical rainforest gaps and tree species diversity. Annual Review of Ecology and Systematics 18: 431-51.

Do TV, Cam NV, Sato T, Binh NT, Kozan O, Thang NT \& Mitlohner R. 2016. Post-logging regeneration and growth of commercially valuable tree species in evergreen broadleaf forest, Vietnam. Journal of Tropical Forest Science 28: 426-435.

Evans GC \& CoOmbe DE. 1959. Hemispherical and woodland canopy photography and light climate. Journal of Ecology 47: 103-113.

Gillison AN \& BREWER KRW. 1985. The use of gradient directed transects or gradsects in national resource survey. Journal of Environmental Management 20: 103-127.

GreEN PT. 1996. Canopy gaps in rain forest on Christmas Island, Indian Ocean: size distribution and methods of measurement. Journal of Tropical Ecology 12: 427-434.

Huston MA. 1994. Biological Diversity: The Coexistence of Species on Changing Landscape. Cambridge University Press, London.

JoHns JS, BARRETo P \& UHL C. 1996. Logging damage during planned and unplanned logging operations in the eastern Amazon. Forest Ecology and Management 89: 59-77.

JoHns AD. 1988. Effects of "selective" timber extraction on rain forest structure and composition and some consequences for frugivores and folivores. Biotropica 20: 31-37.

Kato R, TADAKI Y \& OgaWa H. 1978. Plant biomass and growth increment studies in Pasoh Forest Reserve. Malay Nature Journal 30: 211-224.

Magurran AE. 1988. Ecological Diversity and Its Measurement. Chapman and Hall Publishers, New York.

Ne Win R, Suzuki R \& TAKeda S. 2012. Effects of selective logging on the regeneration of two commercial tree species in the Kabaung Reserved Forest, Bago Mountains, Myanmar. Journal of Tropical Forest Science 24: 312-321.

Numata S, Yasuda M, Okuda T, Kachi N \& Nur Supardi MN. 2006. Canopy gap dynamics of two different forest stands in a Malaysian lowland rain forest. Journal of Tropical Forest Science 18: 109-116.

Periera R, Zweede JC, Asner GP \& Keller M. 2002. Forest canopy damage and recovery in reduced-impact and conventional selective logging in eastern Para, Brazil. Forest Ecology and Management 168: 77-89.

Pinagé ER, Matricardi EAT, Leal FA \& Pedlowski MA. 2016. Estimates of selective logging impacts in tropical 
forest canopy cover using RapidEye imagery and field data. iForest 9: 461-468.

Pinagé ER, Matricardi EAT, Osako LS \& Gomes AR. 2014. Gap fraction estimates over selectively logged forests in Western Amazon. Natural Resources 5: 969-980.

Popma J, Bongers F, Martinez-Ramos M \& Veneklaas E. 1988. Pioneers species distribution in treefall gaps in neotropical rain forest: a gap definition and its consequences. Journal of Tropical Ecology 4: 77-88.

Priatna D. Kartawinata K \& Abdulhadi R. 2004. Recovery of a lowland dipterocarp forest twenty two years after selective logging at Sekundur, Gunung Leuser National Park, North Sumatra, Indonesia. Reinwardtia 12: 237-255.

RRIM. 1988. Training Manual on Soil, Management of Soils and Nutrition of Hevea. Rubber Research Institute Malaysia, Sungai Buloh.

SAIFUL I. 2002. Effects of selective logging on tree species diversity, stand structure and physical environment of tropical hill dipterocarp forest of Peninsular Malaysia. PhD thesis. Universiti Kebangsaan Malaysia, UKM, Bangi.

Saiful I, Shukor MN, Faridah-Hanum I \& Latiff A. 2010. Spatial variation of physical environment and environmental aspect of selective logging: a case study of tropical hill dipterocarp forests of Peninsular Malaysia. Malaysian Forester 73: 33-51.

SAIful I \& LatifF A. 2014. Effects of selective logging on tree species composition, richness and diversity in a hill dipterocarp forest in Malaysia. Journal of Tropical Forest Science 26: 188-202.

Saiful I \& Latiff A. 2017. Stand profile topography of a primary hill dipterocarp forest in Peninsular Malaysia. Journal of Tropical Forest Science 29: 137-150.

Schulze M \& ZweEde J. 2006. Canopy dynamics in unlogged and logged forest stands in the eastern Amazon. Forest Ecology and Management 236: 56-64.

Seino T, Takyu M, Aiba S, Kitayama K \& Ong R. 2005. Floristic composition, stand structure, and above-ground biomass of the tropical rain forests of Deramakot and Tangkulap Forest Reserve in Malaysia under different forest managements. Pp 29-52 in Lee YF et al. (eds) Proceedings of the 2nd Workshop on Synergy between Carbon Management and Biodiversity Conservation in Tropical Rain Forests. DIWPA, Kyoto.
SLAma CC. 1980. Manual of Photogrammetry. American Society of Photogrammetry, New York.

Soemarno S. 2001. Struktur dan komposisi vegetasi pada petak tebang dan pola pemulihan tapak prasarana pasca pembalakan mekanis diSekundur, Taman Nasional Gunung Leuser. MSc thesis. Universitas Indonesia, Depok.

Thompson J, Proctor J, Viana V, Milliken W, Ratter Ja \& ScotT DA. 1992. Ecological studies in a lowland evergreen rain forest on Maraca Island, Roraima, Brazil. I. Physical environment, forest structure, and leaf chemistry. Journal of Ecology 80: 689-703.

Uhl C \& VIeIRA ICG. 1989. Ecological impacts of selective logging in the Brazilian Amazon: a case study from the Paragominas region of the State of Para. Biotropica 21: 98-106.

Vandermeer PJ \& Bongers F. 1996. Patterns of tree fall and branch fall in a tropical rain forest in French Guiana. Journal of Ecology 84: 19-29.

Verissimo A, Barreto P, Mattos M, Tarifa R \& Uhl C. 1992. Logging impacts and prospects for sustainable forest management in an old Amazonian frontier: the case of Paragominas. Forest Ecology and Management 55: 169-199.

Wевв EL. 1997. Canopy removal and residual stand damage during controlled selective logging in lowland swamp forest of northeast Costa Rica. Forest Ecology and Management 95: 117-129

Whitmore TC. 1984. Tropical Rain Forests of the Far East. $2^{\text {nd }}$ edition. Clarendon Press, Oxford.

Whitmore TC. 1989. Canopy gaps and the two major groups of forest trees. Ecology 70: 536-538.

Whitmore TC. 1990. An Introduction to Tropical Rain Forests. Clarendon Press, Oxford.

Whitmore TC, Brown ND, Swaine MD, Kennedy D, GoodwinBAILEY CI \& Gong WK. 1993. Use of hemispherical photographs in forest ecology: measurement of gap size and radiation totals in a Bornean tropical rain forest. Journal of Tropical Ecology 9: 131-151.

Yuan CT, KeONG GB \& Weinland G. 1996. The silviculture of logged-over forests in Peninsular Malaysia: current practice and future challenges. Malaysian Forester 59: 18-38. 
Appendix 1 Calculation of Photo Scale and Gap Area Measurements

For example, the distance between two points a and b of a canopy gap photograph was measured as $12.7 \mathrm{~cm}$ with their corresponding ground distance $\mathrm{AB}$ as $13 \mathrm{~m}(1300 \mathrm{~cm})$. Based on this data, calculation would be as follows:

\section{Step 1: Calculation of Photo Scale}

Scale 'S' $=\frac{\mathrm{ab}}{\mathrm{AB}}=\frac{\text { Photo Distance }}{\text { Ground Distance in Centimeter }}=\frac{12.7}{1300}=\frac{1}{102.36}=1: 102.36$

At a given distance, on the ground is 102.36 times greater than the photograph.

\section{Step 2: Gap area measurements}

From the above photo scale, $1 \mathrm{~cm}^{2}$ on the photograph $=(102.36 \mathrm{~cm})^{2}=10477.57 \mathrm{~cm}^{2}$ on the ground. Size of the canopy photograph $(3 \mathrm{R}$ size print $)=8.9 \times 12.6 \mathrm{~cm}=112.14 \mathrm{~cm}^{2}=1120$ dot.

Thus, $1 \mathrm{~cm}^{2}$ (on the photograph $)=\frac{1120}{112.14}=10$ dots $=10477.57 \mathrm{~cm}^{2}$ on the ground

Thus, $1 \mathrm{dot}=10447.57 / 10=1047.76 \mathrm{~cm}^{2}=0.105 \mathrm{~m}^{2}$

Total number of dots counted for this gap $=429$.

So, gap size $=429 \times 0.105=45.0 \mathrm{~m}^{2}$ 